\title{
Evaluasi Kinerja Dosen dan Tenaga Kependidikan Selama Work From Home (Wfh): Studi Kasus Di Universitas Negeri Surabaya
}

\author{
Suprapto \\ Prodi S1 Pendidikan Teknik Bangunan, FT, Universitas Negeri Surabaya \\ Email: suprapto@unesa.ac.id \\ Suparji \\ Prodi S3 Pendidikan Vokasi, PPs, Universitas Negeri Surabaya \\ Email: suparji@unesa.ac.id \\ Sugeng Harianto \\ Prodi S1 Sosiologi, FISH, Universitas Negeri Surabaya \\ Email: sugengharianto@unesa.ac.id \\ Aisyah Endah Palupi \\ Prodi S1 Teknik Mesin, FT, Universitas Negeri Surabaya, \\ Email: aisyahpalupi@unesa.ac.id \\ Suwarno Imam Samsul \\ Prodi S1 Pendidikan Bahasa Jerman, FBS, Universitas Negeri Surabaya \\ Email: suwarnoimams@unesa.ac.id
}

\begin{abstract}
This study aimed to describe the performance of lecturers and administration staff at Universitas Negeri Surabaya (Unesa) during the Covid-19 Pandemic. This study was conducted in Unesa during the Covid-19 pandemic, from March to October 2020. This study was designed as a population study, namely research using all populations as samples that included all Unesa lecturers and administration staffs. The data were collected using open and closed questionnaires with the respondents from lecturers, Head of Subdivisions, and students. The obtained data were analyzed using quantitative descriptive analysis with narrative explanation. The data portrayed the following conclusions: (1) In coping with the Unesa administration staffs' performance based on the Head's evaluation, the Head of Subdivision gave excellent appreciation with a mean score of 3.31 ; $(2)$ In accordance with the Unesa administration staff's performance based on student assessment, the students gave a very good score with a mean score of 3.21 ; (3) Student assessment of lecturer's performance for each faculty and postgraduate program, the highest planning score was postgraduate with an average score of 3.62 and the lowest score was the Faculty of Sports Science with an average score of 3.27, the highest implementation score was postgraduate with a mean score of 3.61 and the lowest was The Faculty of Sports Science with an average score of 3.2, the highest evaluation score was postgraduate with a score of 3.60 and the lowest was the Faculty of Sports Science with a score of 3.26; (4) based on the self-assessment of lecturer performance, the three biggest problems and constraints were $35.15 \%$ of signal problems; $20.78 \%$ of problems with costs and limited internet quota; and $12.84 \%$ of literacy problems. Three suggestions for improvements for online lectures were $33.87 \%$ of requirment to improve Vinesa: $32.80 \%$ of assistance with facilities and $8.28 \%$ of training/preparation/online lecture manuals.
\end{abstract}

Keywords: Pandemic Covid 19, Work from Home, Online Lectures, Performance, Lecturers, administration staff

Abstrak

Penelitian ini bertujuan mendeskripsikan kinerja dosen dan tenaga kependidikan Universitas Negeri Surabaya (Unesa) selama masa Pandemi Covid-19. Penelitian ini dilakukan di Unesa selama pandemi Covid-19 yaitu bulan Maret sampai dengan bulan Oktober 2020. Penelitian ini didesain sebagai penelitian populasi yaitu penelitian dengan menggunakan semua populasi sebagai sampel yaitu semua dosen dan tenaga kependidikan Unesa. Data diambil menggunakan teknik pengambilan data berupa angket terbuka dan tertutup dengan responden dosen, Kepala Sub Bagian dan mahasiswa. Data akan dianalisis dengan analisis deskriptif kuantitatif dengan penjelasan secara narasi. Data hasil penelitian memperoleh simpulan sebagai berikut: (1) Kinerja Tendik seluruh Unesa Berdasarkan Penilaian Atasan, Kasubbag memberikan apresiasi

Article history: Received,13 April 2021; Resivised 07 Mei 2021; Accepted, 10 Mei 2021.

Corresponding author(s): Aisyah Endah Palupi ,Email: aisyahpalupi@unesa.ac.id

To cite this article: Suprapto, Suparji, Harianto, S., Palupi, A. E., \& Samsul, S. I. (2021). Evaluasi Kinerja Dosen dan Tenaga Kependidikan Selama Work From Home (WFH): Studi Kasus di Universitas Negeri Surabaya, 05(2), 90-100. https://doi.org/10.26740/jpsi.v5n2.p90-99 
yang sangat baik dengan skor rerata 3,31; (2) Rerata Kinerja Tendik seluruh Unesa berdasarkan Penilaian Mahasiswa memberikan penilaian sangat baik dengan skor rerata 3,21; (3) Penilaian Mahasiswa terhadap Kinerja Perkuliahan Dosen Setiap Fakultas dan Pascasarjana, tahap perencanaan skor tertinggi adalah Pascasarjana dengan skor rerata 3,62 dan terendah Fakultas IImu Olahraga dengan skor rerata 3,27, tahap pelaksanaan tertinggi Pascasarjana dengan skor rerata 3,61 dan terendah Fakultas Ilmu Olahraga dengan skor rerata 3,2, tahap evaluasi tertinggi Pascasarjana dengan skor 3,60 dan terendah Fakultas IImu Olahraga dengan skor 3,26; (4) Berdasarkan Self Assesment Kinerja Dosen, tiga permasalahan dan kendala terbesar adalah 35,15\% masalah signal; 20,78\% masalah biaya dan keterbatasan kuota internet; dan 12,84\% masalah literasi. Tiga saran perbaikan untuk perkuliahan on line adalah $33,87 \%$ perlu dilakukannya penyempurnaan Vinesa; 32,80\% bantuan fasilitas dan 8,28\% adanya pelatihan/persiapan/buku pedoman kuliah daring.

Kata Kunci: Pandemi Covid 19, Work from Home, Kuliah Daring, Kinerja, Dosen, Tenaga Kependidikan

\section{PENDAHULUAN}

Sejak awal bulan Maret 2020, dunia dihebohkan dengan wabah pandemi akibat penyebaran Virus Corona (Covid-19) yang menyebabkan beragam kepanikan, salah satunya di ranah pendidikan tinggi, termasuk Unesa. Oleh karena itu Unesa harus menerapkan strategi dengan cara WfH bagi dosen dan tendik, penjadwalan piket bagi pimpinan dan tendik, serta aktifitas daring (on line) lainnya.

Kuliah yang normalnya dilakukan dengan tatap muka di kelas dan blended learning harus berubah format menjadi perkuliahan daring sepenuhnya. Bagi dosen, mahasiswa, dan institusi kampus yang terbiasa dengan perkuliahan daring, format perkuliahan dengan memanfaatkan teknologi informasi berbasis internet ini tidak menjadi persoalan. Mereka cukup menambah porsi pertemuan daringnya, atau mengganti sesi tatap muka di kelas menjadi pertemuan daring di internet. Namun hal ini tidak semudah yang dibayangkan bagi mata kuliah yang memerlukan eksperimen untuk menjelaskan materinya kepada mahasiswa, karena tidak semua program studi memiliki laboratorium virtual yang digunakan sebagai fasilitas perkuliahan.

Kondisi saat ini di tengah penyebaran virus corona (Covid-19) yang semakin meluas, kuliah daring (online) menjadi solusi untuk tetap menjalankan kegiatan belajarmengajar sebagai pengganti pertemuan di kelas. Di tengah pandemi Covid-19, yang diprediksi puncaknya di Indonesia pada pertengahan bulan April ini, Unesa memberlakukan aturan perkuliahan secara online terhitung sejak 14 Maret 2020 hingga pemberitahuan lebih lanjut, berdasarkan Surat Edaran Rektor Nomor: B/15254/UN38/TU.00.02/2020. Selain itu, program akademik lainnya seperti Skripsi, Praktik Industri (PI), Praktik Kerja Lapangan (PKL), dan Tugas Akhir (TA) bagi Program Diploma juga harus dilakukan secara daring.

Sistem penggantian kuliah tatap muka dengan kuliah daring (kuldar) merupakan keniscahyaan pada masa pandemik. Walaupun demikian, perlu juga dilakukan monitoring dan evaluasi (monev) terhadap pelaksanaan kuliah daring, sehingga tingkat ketercapaian kualitas perkuliahan dan kepuasan mahasiswa tetap terjaga. Kemungkian masalah yang timbul dengan sistem perkuliahan daring ini dapat dilihat dari berbagai aspek, seperti: aspek ekonomi, aspek teknologi, dan aspek tanggungjawab.

Bidang kepegawaian, juga mengalami hal yang sama di masa pandemik ini, yaitu melakukan tugasnya dengan sistem Work from Home (WfH), penjadwalan piket, dan lembur. Pemberlakuan sistem baru selama masa pandemik ini, bukan berarti mengurangi kualitas kinerja tendik sesuai Prosedur Operasional Standar (POS). Akan tetapi hal itu masih perlu untuk dikaji lebih lanjut ketercapaian kinerja tendik selama WFH, karena memang tidak mudah untuk mengubah budaya kerja yang semula bekerja di kantor menjadi bekerja di rumah.

Dari semua permasalah di atas perlu dilakukan evaluasi kinerja Dosen dan Tendik selama masa WfH. Permasalahan utama dapat dirumuskan dengan tujuan untuk mendeskripsikan kinerja dosen dan tenaga kependidikan Unesa selama WfH

\section{METODE}

Penelitian ini adalah penelitian evaluasi dengan survey. Subjek penelitian dosen sebanyak 938 orang dan Tenaga Kependidikan sebanyak 69 orang, sehingga jumlahnya adalah 1.007 orang. Responden untuk mengisi instrumen terdiri dari 914 dosen, Kasubag 43 orang, dan 26.475 mahasiswa. Kinerja Dosen dinilai oleh mahasiswa dan penilaian diri. Tenaga kependidikan dinilai oleh kasubag dan mahasiswa. Teknik pengumpulan data menggunakan kuesinoner dengan instrumen angket tertutup dan angket terbuka. Analisis dilakukan dengan menggunakan statistik deskriptif.

\section{HASIL DAN PEMBAHASAN}

Menurut Gibson, et.all. (1995:364), setiap pegawai dalam organisasi dituntut untuk memberikan kontribusi positif melalui kinerja yang baik, mengingat kinerja organisasi tergantung pada kinerja pegawainya. Kinerja adalah tingkat terhadapnya para pegawai mencapai persyaratan pekerjaan secara efisien dan efektif (Simamora, 2006:34). Kinerja pegawai merupakan prestasi kerja, yakni perbandingan antara hasil kerja yang dapat dilihat secara nyata dengan standar kerja yang telah ditetapkan organisasi. Kemudian Robbins (2008) mendefinisikan kinerja yaitu suatu hasil yang dicapai oleh pegawai dalam pekerjaanya menurut kriteria tertentu yang berlaku untuk suatu pekerjaan. Mangkunegara (2005:67) kinerja ialah hasil kerja baik secara kualitas maupun kuantitas yang dicapai oleh seorang pegawai dalam melakukan tugas sesuai dengan tanggung jawab yang diberikan kepadanya. Sedangkan Rivai (2009:532) kinerja diartikan kesediaan seseorang atau kelompok orang untuk melakukan suatu kegiatan, dan menyempurnakannya sesuai tanggung jawabnya dengan hasil seperti yang diharapkan. Berdasarkan beberapa pengertian kinerja oleh para ahli di atas, dapat dikatakan bahwa kinerja merupakan hasil kerja, baik kualitas maupun kuantitas, 
yang telah dicapai pegawai, dalam menjalankan tugastugasnya sesuai dengan tanggung jawab yang diberikan organisasi, dan hasil kerjanya tersebut disesuaikan dengan hasil kerja yang diharapkan organisasi, melalui kriteriakriteria atau standar kinerja pegawai dalam organisasi.

Berdasarkan pengertian kinerja di atas, berikut ini diuraikan kinerja pegawai (tendik dan dosen) Unesa berdasarkan penilaian atasan, mahasiswa, dan self assessment selama Pandemi Covid 19. Selama Pandemi Covid 19 tendik bekerja dengan sistem piket dan work from home (WfH), sedangkan dosen melaksanakan kegiatan Tri Dharma (pengajaran, penelitian, dan pengabdian kepada masyarakat) melaui sistem WfH.

\section{Kinerja Tenaga Kependidikan berdasarkan Penilaian Atasan secara keseluruhan \\ Hasil kerja tenaga kependidikan baik secara kuantitas dan kualitas dan kesesuaian dengan hasil kerja yang diharapkan oleh organisasi dapat dilihat dari penilaian yang dilakukan atasan. Atasan yang memberikan penilaian terhadap kinerja tenaga kependidikan adalah Kepala Sub Bagian (Kasubbag) di masing-masing unit kerja. Atasan memberikan penilaian terhadap tenaga kependidikan berdasarkan pengamatan dan hasil kerja tenaga kependidikan.}

Atasan menilai kinerja tenaga kependidikan dengan menggunakan 16 indikator, yaitu: (1) memberikan layanan sesuai dengan SOP; (2) memiliki kemampuan yang baik dalam memenuhi permintaan pengguna; (3) memiliki inovasi dalam melaksanakan tugas; (4) melaksanakan tugas dengan penuh kedisiplinan; (5) memiliki tanggungjawab yang tinggi; (6) bersikap ramah; (7) bersikap bersahabat; (8) melaksanakan tugas secara adil; (9) layanan yang diberikan tepat waktu; (10) memberikan layanan secara efisien; (11) memiliki kemampuan kerja yang tinggi; (12) kualitas hasil kerja sangat memuaskan; (13) mempunyai kemampuan kerjasama yang baik dalam menyelesaikan hasil kerja; (14) kuantitas hasil kerja sesuai target; (15) kemampuan melaksanakan tugas secara online sangat baik; dan (16) pelaksanaan tugas dari rumah (WFH), dilengkapi dengan fasilitas pribadi.

Kasubbag menilai kinerja tenaga kependidikan yang menjadi bawahannya dengan menggunakan 16 indikator tersebut. Hasil riset menunjukkan bahwa para Kasubbag di lingkungan Unesa memberikan penilaian sangat baik terhadap kinerja tenaga kependidikan untuk semua indikator selama Pandemi Covid 19, baik selama bekerja di kantor maupun di rumah. Penilaian ini menunjukkan bahwa tenaga kependidikan selama masa Pandemi Covid 19 tetap melaksanakan fungsi-fungsi pelayanan secara baik. Kasubbag menilai kinerja tenaga kependidikan tidak hanya dari aspek pelayanan kepada mahasiswa, tetapi juga fungsifungsi pelayanan yang lain yang tidak terkait dengan pelayanan mahasiswa seperti keuangan, barang milik negara (BMN), kepegawaian, kerumahtanggaan, dan sebagaianya. Penilaian atasan terhadap kinerja tenaga kependidikan Unesa dapat dilihat pada gambar di bawah ini.

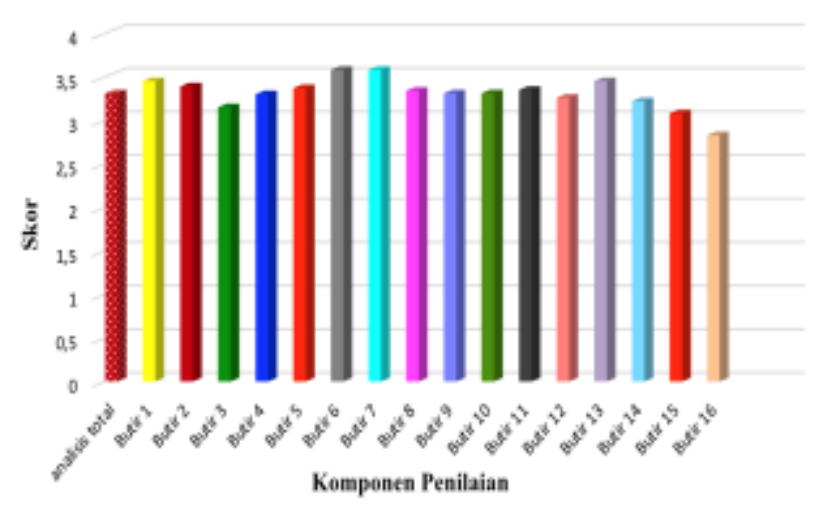

Sumber: Data Hasil Penelitian

\section{Gambar 1. Penilaian Atasan terhadap Kinerja Tendik Unesa}

Berdasarkan penilaian atasan ini, untuk beberapa indikator kinerja tenaga kependidikan lebih baik daripada penilaian mahasiswa. Para Kasubbag memberikan apresiasi yang sangat baik terhadap kinerja tenaga kependidikan untuk inidkator atau aspek: (1) memberikan layanan sesuai dengan SOP; (2) bersikap ramah; (3) bersikap bersahabat; dan (4) mempunyai kemampuan kerjasama yang baik dalam menyelesaikan hasil kerja. Tenaga kependidikan dinilai sangat baik pada 4 aspek tersebut. Meskipun demikian atasan merasa belum puas terhadap kinerja tenaga kependidikan terkait dengan aspek pelaksanaan tugas dari rumah (WFH), dilengkapi dengan fasilitas pribadi. Atasan menilai tenaga kependidikan yang melakukan pekerjaan dari rumah belum didukung dengan fasilitas pribadi yang memadai seperti prasarama meja dan kursi kerja, laptop, deskstop, printer, dan lain-lain. Detil penilaian atasan terhadap kinerja tenaga kependidikan dapat dilihat pada tabel di bawah ini.

Tabel 1. Penilaian Atasan terhadap Kinerja Tendik

\begin{tabular}{|c|l|c|c|}
\hline $\begin{array}{c}\text { No } \\
\text { butir }\end{array}$ & \multicolumn{1}{|c|}{ Perayataan } & Skor & Kategori \\
\hline 1 & Memberikan layanan sesuai dengan SOP & 3,45 & sangat tinggi \\
\hline 2 & $\begin{array}{l}\text { Memiliki kemampuan yang baik dalam memenuhi } \\
\text { permintan pengguna }\end{array}$ & 3,39 & sangat tinggi \\
\hline 3 & Memiliki inovasi dalam melaksanakan tugas & 3,15 & tinggi \\
\hline 4 & Melaksanakan tugas dengan penuh kedisiplinan & 3,30 & sangat tinggi \\
\hline 5 & Memiliki tanggungjawab yang tinggi & 3,37 & sangat tinggi \\
\hline 6 & Bersikap ramah & 3,58 & sangat tinggi \\
\hline 7 & Bersikap bersahabat & 3,58 & sangat tinggi \\
\hline 8 & Melaksanakan tugas secura adil & 3,34 & sangat tinggi \\
\hline 9 & Layanan yang diberikan tepat waktu & 3,31 & sangat tinggi \\
\hline 10 & Memberikan layanan secara efisien & 3,31 & sangat tinggi \\
\hline 11 & Memiliki kemampuan kerja yang tinggi & 3,35 & sangat tinggi \\
\hline 12 & Kualitas hasil kerja sangat memuaskan & 3,26 & sangat tinggi \\
\hline 13 & $\begin{array}{l}\text { Mempanyai kemampuan kerjasama yang baik dalam } \\
\text { menyelesaikan hasil keria }\end{array}$ & 3,45 & sangat tinggi \\
\hline 14 & Kuantitas hasil kerja sesuai target & 3,22 & tinggi \\
\hline 15 & $\begin{array}{l}\text { Kemampaan melaksanakan tugas secara oulike sangat } \\
\text { baik }\end{array}$ & 3,08 & tinggi \\
\hline 16 & $\begin{array}{l}\text { Pelaksanaan tugas dari rumah (WFH), dilengkapi } \\
\text { dengan fasilitas pribadi }\end{array}$ & 2,83 & sedang \\
\hline & & 3,31 & sangat tinggi \\
\hline
\end{tabular}

Sumber: Data Hasil Penelitian

\section{Kinerja Tendik Berdasarkan Penilaian Mahasiswa}

Hasil kerja Tendik baik secara kuantitas dan kualitas dan kesesuaian dengan hasil kerja yang diharapkan oleh organisasi, selain oleh atasan, juga dapat dilihat dari penilaian mahasiswa. Data mahasiswa yang memberikan 
penilaian terhadap kinerja tendik diperoleh dari SIAKAD yang diisi sebelum mahasiswa yang bersangkutan mengisi sistem untuk memprogram mata kuliah yang diambil pada semester Gasal 2020/2021. Data isian atas penilaian kinerja tendik oleh mahasiswa yang diperoleh adalah dari seluruh fakultas yang dimiliki Unesa dan juga Pascasarjana. Tendik yang dipilih untuk dinilai mahasiswa adalah tendik yang dalam menjalankan tugasnya di Prodi, terkait langsung dengan urusan kemahasiswaan di prodinya masing-masing.

Indikator penilaian mahasiswa atas tendik, sama dengan penilaian dari atasan, yaitu: (1) memberikan layanan sesuai dengan SOP; (2) memiliki kemampuan yang baik dalam memenuhi permintaan pengguna; (3) memiliki inovasi dalam melaksanakan tugas; (4) melaksanakan tugas dengan penuh kedisiplinan; (5) memiliki tanggungjawab yang tinggi; (6) bersikap ramah; (7) bersikap bersahabat; (8) melaksanakan tugas secara adil; (9) layanan yang diberikan tepat waktu; (10) memberikan layanan secara efisien; (11) memiliki kemampuan kerja yang tinggi; (12) kualitas hasil kerja sangat memuaskan; (13) mempunyai kemampuan kerjasama yang baik dalam menyelesaikan hasil kerja; (14) kuantitas hasil kerja sesuai target; (15) kemampuan melaksanakan tugas secara online sangat baik; dan (16) pelaksanaan tugas dari rumah $(\mathrm{WfH})$, dilengkapi dengan fasilitas pribadi.

Hasil riset menunjukkan bahwa mahasiswa memberikan penilaian baik terhadap kinerja tenaga kependidikan untuk semua indikator selama Pandemi Covid 19, baik selama bekerja di kantor maupun di rumah. Penilaian ini menunjukkan bahwa tenaga kependidikan selama masa Pandemi Covid 19 tetap melaksanakan fungsi-fungsi pelayanan secara baik. Mahasiswa masih tetap merasa terlayani dengan baik meskipun secara daring, untuk urusan terkait dengan keuangan, registrasi, kelancaran perkuliahan, nilai, dan sebagaianya. Penilaian mahasiswa terhadap kinerja tenaga kependidikan Unesa dapat dilihat pada gambar di bawah ini.

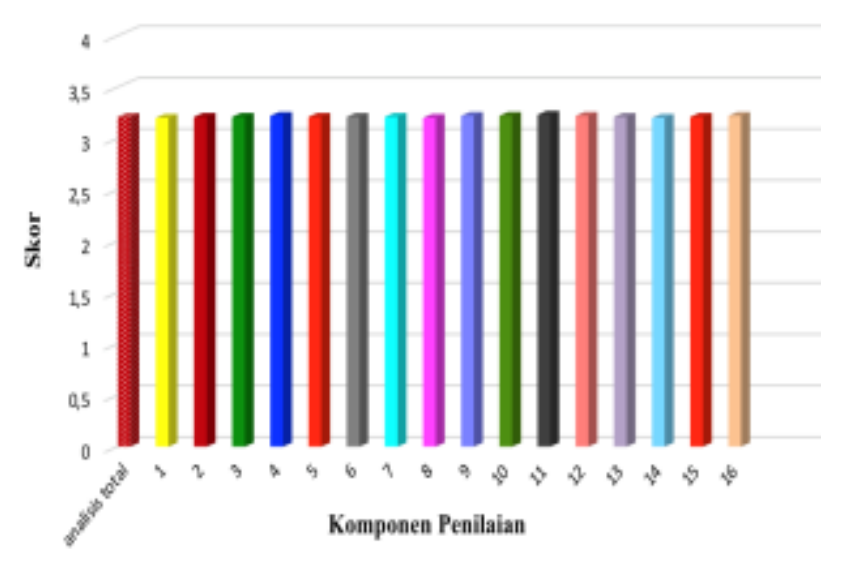

Sumber: Data Hasil Penelitian

Gambar 2. Rerata Penilaian Mahasiswa terhadap Kinerja Tendik Unesa
Berdasarkan penilaian mahasiswa ini, untuk beberapa indikator kinerja tendik lebih rendah daripada penilaian atasan. Para mahasiswa memberikan apresiasi yang rata-rata sama untuk semua indikator seperti yang terlihat pada Tabel 2 Dari hasil tersebut, sepertinya masih perlu ditingkatkan mengenai pelayanan tendik bagi mahasiswa, terutama di masa pandemic ini dimana sebagian besar pelayanan yang diberikan melalui on line. Hal tersebut dapat dilakukan dengan cara memberikan fasilitas jaringan internet yang memadai, baik di jurusan masing-masing maupun memberikan bantuan paket data bagi tendik yang sedang $\mathrm{WfH}$.

Tabel 2. Penilaian Mahasiswa terhadap Kinerja Tendik

\begin{tabular}{|c|l|c|c|}
\hline $\begin{array}{c}\text { No } \\
\text { butir }\end{array}$ & \multicolumn{1}{|c|}{ Pernyataan } & Skor & Kategori \\
\hline 1 & Memberikan layanan sesuai dengan SOP & 3,21 & tinggi \\
\hline 2 & $\begin{array}{l}\text { Memiliki kemampuan yang baik dalam memenuhi } \\
\text { permintaan pengguna }\end{array}$ & 3,20 & tinggi \\
\hline 3 & Memiliki inovasi dalam melaksanakan tugas & 3,21 & tinggi \\
\hline 4 & Melaksanakan tugas dengan penuh kedisiplinan & 3,22 & tinggi \\
\hline 5 & Metailiki tanggungawab yang tinggi & 3,21 & tinggi \\
\hline 6 & Bersikap ramah & 3,21 & tinggi \\
\hline 7 & Bersikap bersahabat & 3,21 & tinggi \\
\hline 8 & Melaksanakan tugas secana adil & 3,20 & tinggi \\
\hline 9 & Layanan yang diberikan tepat waktu & 3,22 & tinggi \\
\hline 10 & Memberikan layanan secara efisien & 3,22 & tinggi \\
\hline 11 & Memiliki kemampuan kerja yang tinggi & 3,23 & tinggi \\
\hline 12 & Kualitas hasil kerja sangat memuaskan & 3,22 & tinggi \\
\hline 13 & $\begin{array}{l}\text { Mempunyai kemampuan kerjasama yang baik dalam } \\
\text { metryelesaikan hasil keria }\end{array}$ & 3,21 & tinggi \\
\hline 14 & Kuantitas hasil kerja sesuai target & 3,20 & tinggi \\
\hline 15 & Kemampuan melaksanakan tagas secan anline sangat baik & 3,21 & tinggi \\
\hline 16 & $\begin{array}{l}\text { Pelaksanaan tugas dari rumah (WFH), dilengkapi dengan } \\
\text { fasilitas pribadi }\end{array}$ & 3,22 & tinggi \\
\hline & & 3,21 & tinggi \\
\hline
\end{tabular}

Sumber: Data Hasil Penelitian

\section{Penilaian Mahasiswa terhadap Kinerja Perkuliahan Dosen secara keseluruhan}

Sebelum melaksanakan pembelajaran secara daring dosen harus mempersiapkan kegiatan perkuliahan, termasuk evaluasi pembelajaran. Kegiatan pembelajaran disesuaikan dengan kondisi Pandemi Covid 19. Kegiatan pembelajaran tatap muka digantikan dengan kegiatan pembelajaran daring. Demikian pula, evaluasi yang biasanya diselenggarakan di dalam kelas digantikan dengan evaluasi secara daring. Mahasiswa memberikan penilaian terhadap kinerja perencanaan perkuliahan yang disusun oleh dosen. Mahasiswa melakukan penilaian terhadap persiapan perkuliahan yang dilakukan dosen terkait dengan 3 indikator, yaitu: (1) RPS dan materi sudah disiapkan dosen; (2) dosen menyampaikan skenario perkuliahan daring selama Pandemi ke mahasiswa; dan (3) kesesuaian pelaksanaan jumlah tatap muka dalam satu semester (15 kali pertemuan).

Hasil riset menunjukkan bahwa mahasiswa menilai sangat baik terhadap persiapan kegiatan perkuliahan yang dilakukan oleh dosen. Data yang tersaji dalam Gambar 3 dan Tabel 3 menunjukkan mahasiswa memberikan skor sangat tinggi untuk 3 indikator kinerja. Data ini menunjukkan dosen telah memersiapkan kegiatan perkuliahan dengan sangat baik. Dalam penilaian mahasiswa dosen telah menyusun RPS dan telah menyiapkan materi perkuliahan dengan sangat baik. Dalam penilaian mahasiswa, dosen juga telah 
menyampaikan skenario perkuliahan daring ke mahasiswa dengan sangat baik. Dosen juga dinilai sangat baik terkait kesesuaian pelaksanaan kegiatan pembelajaran daring dalam satu semester. Hal ini menunjukkan bahwa dalam kegiatan persiapan perkuliahan dosen tidak menghadapi masalah atau kendala selama Pandemi Covid 19. Profil kinerja persiapan perkuliahan dosen berdasarkan penilaian mahasiswa tersaji dalam gambar dan tabel di bawah ini.

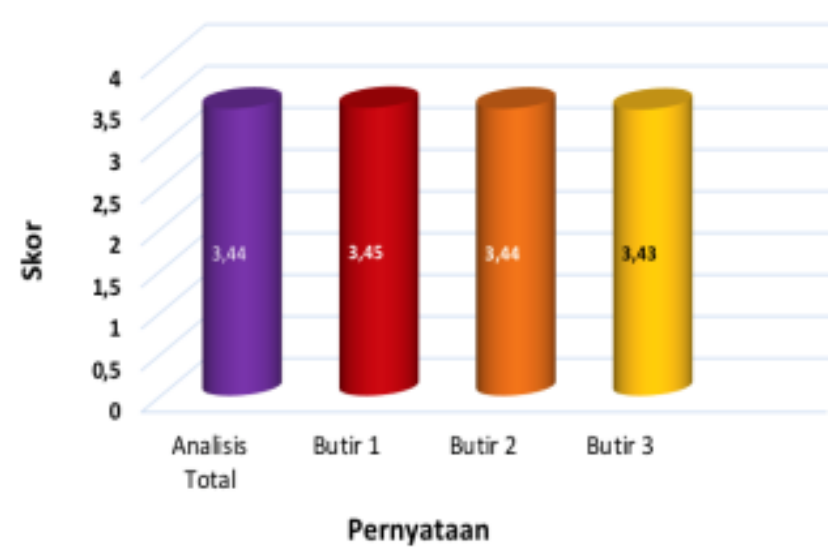

Sumber: Data Hasil Penelitian

Gambar 3. Penilaian Mahasiswa terhadap Kinerja Persiapan Perkuliahan Dosen

Tabel 3. Penilaian Mahasiswa terhadap Kinerja Persiapan Kuliah

\begin{tabular}{|c|l|c|}
\hline No. & \multicolumn{1}{|c|}{ Pernyataan } & Skor \\
\hline 1. & RPS dan materi sudah disiapkan dosen & 3,45 \\
\hline 2. & $\begin{array}{l}\text { Dosen menyampaikan desain/skenario perkuliahan } \\
\text { daring selama masa Pandemik, ke mahasiswa }\end{array}$ & 3,44 \\
\hline 3. & $\begin{array}{l}\text { Kesesuaian pelaksanaan jumlah tatap muka dalam satu } \\
\text { semester (15 kali pertemuan) }\end{array}$ & 3,43 \\
\hline & \multicolumn{1}{|c|}{ Rata-rata } & 3,44 \\
\hline
\end{tabular}

Sumber: Data Hasil Penelitian

Setelah mempersiapkan perkuliahan, dosen melaksanakan kegiatan perkuliahan daring kepada mahasiswa. Data riset menunjukkan bahwa mahasiswa memberikan penilaian terhadap 12 indikator pelaksanaan perkuliahan sangat baik. Hal ini menunjukkan bahwa selama Pandemi Covid 19 dosen telah memberikan pelayanan pembelajaran daring kepada mahasiswa sangat baik. Secara keseluruhan mahasiswa memberikan skor sangat tinggi yaitu 3,42 untuk kinerja pelaksanaan perkuliahan yang dilakukan oleh dosen. Meskipun demikian, sebagian mahasiswa memberikan penilaian baik dan cukup baik untuk beberapa indikator kinerja pelaksanaan perkuliahan. Profil kinerja pelaksanaan perkuliahan berdasarkan penilaian mahasiswa dapat dilihat pada gambar dan tabel di bawah ini.

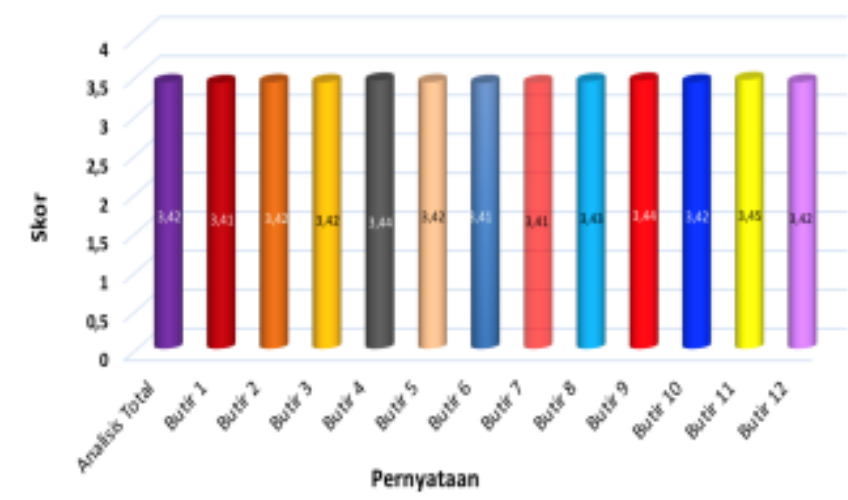

Sumber: Data Hasil Penelitian

Gambar 4. Penilaian Mahasiswa terhadap Kinerja Pelaksanaan Perkuliahan Dosen

Tabel 4. Penilaian Mahasiswa terhadap Pelaksanaan Kuliah

\begin{tabular}{|c|l|c|}
\hline No. & \multicolumn{1}{|c|}{ Pernyataan } & Skor \\
\hline 1. & Pelaksanaan perkuliahan secara daring & 3,41 \\
\hline 2. & Pelaksanaan perkuliahan sesuai jadwal & 3,42 \\
\hline 3. & Kesesuaian materi perkuliahan dengan RPS & 3,42 \\
\hline 4. & Penguasaan materi kuliah & 3,44 \\
\hline 5. & $\begin{array}{l}\text { Kesesuaian metode dan media dengan tujuan } \\
\text { perkuliahan }\end{array}$ & 3,42 \\
\hline 6. & $\begin{array}{l}\text { Kesesuaian tugas struktur dan mandiri dengan bobot } \\
\text { SKS dan tujuan perkuliahan }\end{array}$ & 3,41 \\
\hline 7. & Kemampuan memotivasi mahasiswa untuk belajar & 3,41 \\
\hline 8. & $\begin{array}{l}\text { Pemberian kesempatan bertanya, berpendapat, dan } \\
\text { menjawab pertanyaan }\end{array}$ & 3,43 \\
\hline 9. & $\begin{array}{l}\text { Penggunaan Bahasa Indonesia yang baik dan benar } \\
\text { dalam perkuliahan }\end{array}$ & 3,44 \\
\hline 10. & Keterbukaan menerima kritik dan saran & 3,42 \\
\hline 11. & Penampilan sikap dosen selama kegiatan perkuliahan & 3,45 \\
\hline 12. & $\begin{array}{l}\text { Setiap pertemuan mengisi jumal perkuliahan dan daftar } \\
\text { hadir secara tepat waktu di SIAKADU }\end{array}$ & 3,42 \\
\hline & \multicolumn{1}{c}{ Rata-rata } & 3,42 \\
\hline
\end{tabular}

\section{Sumber: Data Hasil Penelitian}

Dalam dharma pengajaran dosen juga harus melakukan evaluasi pembelajaran setelah melakukan kegiatan pembelajaran kepada mahasiswa. Kegiatan pembelajaran yang biasanya dilaksanakan secara klasikal di kelas, dalam situasi Pandemi Covid 19 ini dilaksanakan secara daring. Kinerja kegiatan evaluasi pembelajaran diukur melalui 7 indikator yaitu: (1) pelaksanaan UTS/UAS sesuai kalender akademik; (2) Pelaksanaan UTS/UAS secara daring; (3) objektivitas dalam memberikan nilai pada mahasiswa; (4) transparansi dalam penetapan nilai-nilai dan pengumuman; (5) kesediaan memberikan ujian susulan; (6) ketepatan waktu dalam penyerahan nilai dan pengumuman ke mahasiswa; dan (7) kesesuaian soal ujian dengan materi perkuliahan. Hasil riset menunjukkan bahwa mahasiswa memberika penilaian sangat baik dengan skor rata-rata 3,42 untuk tujuh indikator kinerja evaluasi pembelajaran yang dilakukan dosen. Pandemi Covid 19 tidak menjadi masalah atau hambatan bagi dosen untuk tetap meakukan evaluasi terhada kinerja pembelajaran mahasiswa. Dalam penilaian mahasiswa dosen melalui daring sangat baik melakukan kegiatan UTS dan UAS sesuai kalender akademik. 
Maasiswa juga memberikan penilaian sangat baik terhadap aspek kesesuaian antara soal ujian dengan materi perkuliahan. Dalam penilaian mahasiswa dosen juga tepat waktu dalam penyarahan nilai dan mengumumkan ke mahasiswa. Hal ini dimungkinkan karena proses penyerahan nilai dan pengumunan kepada masasiswa sudah melalui sistem informasi di Siakadu. Meskipun demikian untuk beberapa aspek mahasiswa memberika penilaian baik dan cukup baik terhadap kegiatan evaluasi pembelajaran yang dilakukan oleh dosen. Profil kinerja evaluasi pembelajaran yang dilakukan dosen berdasarkan penilaian mahasiswa dapat dilihat pada gambar dan tabel di bawah ini.

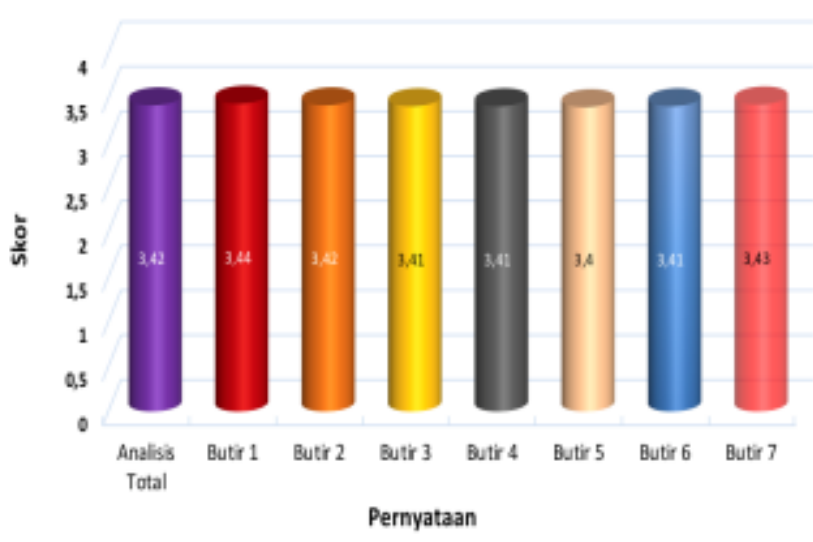

Sumber: Data Hasil Penelitian

Gambar 5. Penilaian Mahasiswa terhadap Kinerja Evaluasi Pembelajaran Dosen

Tabel 5. Penilaian Mahasiswa terhadap Kinerja Evaluasi Hasil Belajar Dosen

\begin{tabular}{|c|c|c|}
\hline No. & Pernyataan & Skor \\
\hline 1. & Pelaksanaan UTS/UAS sesuai kalender akademik & 3,44 \\
\hline 2. & Pelaksanaan UTS/UAS secara daring & 3,42 \\
\hline 3. & Objektivitas dalam memberikan nilai pada mahasiswa & 3,41 \\
\hline 4. & $\begin{array}{l}\text { Transparansi dalam penetapan nilai-nilai dan } \\
\text { pengumuman }\end{array}$ & 3,41 \\
\hline 5. & Kesediaan memberikan ujian susulan & 3,40 \\
\hline 6. & $\begin{array}{l}\text { Ketepatan waktu dalam penyerahan nilai dan } \\
\text { pengumuman ke mahasiswa }\end{array}$ & 3,41 \\
\hline 7. & Kesesuaian soal ujian dengan materi perkuliahan & 3,43 \\
\hline & Rata-rata & 3,42 \\
\hline
\end{tabular}

Sumber: Data Hasil Penelitian

\section{Self Assesment Kinerja Dosen}

Pandemi Covid 19 tidak mengurangi atau menggagalkan kegiatan tri dharma dosen. Meskipun terjadi pandemi dosen harus tetap melaksanakan kegiatan Tri Dharma. Dosen tetap harus melaksanakan dharma pengajaran seperti biasanya. Kegiatan perkuliahan tetap dilaksanakan dalam 16 kali pertemuan, termasuk UTS dan UAS. Oleh karena itu, Rektor Unesa merespon Pandemi Covid 19 mengeluarkan kebijakan melalui surat edaran yang mengatur pelaksanaan kegiatan perkuliahan. Kebijakan Rektor tersebut mengatur pelaksanaan kegiatan perkuliahan dosen dilakukan secara daring. Kebijakan tersebut tidak merekomendasikan kegiatan perkuliahan dilaksanakan di kampus secara tatap muka. Dosen dianjurkan melakukan WfH. Dosen dianjurkan melaksanakan kegiatan perkuliahan secara daring. Namun dalam pelaksanaannya kegiatan perkuliahan di masingmasing fakultas berbeda-beda. Hasil riset menunjukkan bahwa kegiatan perkuliahan setiap matakuliah dilaksanakan secara daring dan luring.

Data riset menunjukkan bahwa secara keseluruhan rata-rata mata kuliah yang menerapkan pembelajaran daring 77,29\% dan sebesar 18,51\% melaksanakan pembelajaran luring. Dengan kata lain, dari 1.821 matakuliah kegiatan perkuliahan daring sebanyak 21.569 tatp muka dan 6.107 tatap muka melaksanakan pembelajaran luring. Data ini menunjukkan belum semua matakuliah melaksanakan pembelajaran daring. Dapat diidentifikasi ada tiga kategori kegiatan pembelajaran selama Pandemi Covid 19 dan WfH, yaitu: pertama, kegiatan pembelajaran yang sepenuhnya daring (virtual learning); kedua, kegiatan pembelajaran campuran antara daring dan luring (blended learning); dan ketiga, pembelajaran yang sepenuhnya luring.

Fakultas Matematika dan Ilmu Pengetahuan Alam (FMIPA) merupakan fakultas yang kegiatan pembelajaran daringnya paling tinggi, yaitu sebesar 97,14\% atau sebanyak 4.080 kali, sedangkan fakultas yang paling sedikit melaksanakan daring adalah Pascasarjana sebesar 63,69\% atau 414 tatap muka, hampir sama dengan FIP yang melaksanakan daring sebesar 69,62\% atau 5.264 tatap muka. Profil kegiatan pembelajaran yang dilakukan selama WfH dapat dilihat pada tabel di bawah ini.

Tabel 6. Kinerja Pembelajaran Daring Dosen Selama WfH

\begin{tabular}{|c|c|c|c|c|c|c|c|}
\hline No. & Fakultas & $\begin{array}{c}\text { Jumlah } \\
\text { matakuliah }\end{array}$ & $\begin{array}{c}\text { On } \\
\text { line }\end{array}$ & $\%$ & off line & $\%$ & $\begin{array}{c}\text { Total } \\
\text { matakuliah }\end{array}$ \\
\hline 1 & FIP & 508 & 5.264 & 69,72 & 2.286 & 30,28 & 7.550 \\
\hline 2 & FBS & 308 & 3.411 & 73,83 & 1.209 & 26,17 & 4.620 \\
\hline 3 & FMIPA & 280 & 4.080 & 97,14 & 120 & 2,86 & 4.200 \\
\hline 4 & FT & 282 & 3.199 & 74,31 & 1.106 & 25,69 & 4.305 \\
\hline 5 & FIO & 84 & 1.055 & 83,73 & 205 & 16,27 & 1.260 \\
\hline 6 & FISH & 310 & 3.619 & 77,83 & 1.031 & 22,17 & 4.650 \\
\hline 7 & FE & 45 & 527 & 78,07 & 148 & 21,93 & 675 \\
\hline 8 & Pascasarjana & 4 & 414 & 63,69 & 2 & 2,67 & 416 \\
\hline & Jumlah & 1.821 & 21.569 & 77,29 & 6.107 & 18,51 & 27.260 \\
\hline
\end{tabular}

\section{Sumber: Data Hasil Penelitian}

Belum sepenuhnya matakuliah melaksanakan kegiatan pembelajaran daring terkait dengan permasalah dan hambatan yang dihadapi oleh dosen. Permasalahan dan kendala yang dihadapi oleh dosen selama WfH terkait dengan masalah-masalah non-akademik seperti signal atau jaringan internet, biaya dan keterbatasn kuota internet, literasi terhadap aplikasi pembelajaran berbasis teknologi informasi rendah, kesulitan mengukur partisipasi dan sikap mahasiswa, dan permasalahan dan kendala lain seperti tersaji pada gambar dan tabel di bawah ini. Sebesar $35,15 \%$ dosen mengaku menghadapi permasalahan dan 
kendala non akademik buruknya signal dan jarngan internet, sebesar 20,78\% menghadapi permasalahan biaya dan keterbatasan kuota internet, sebesar 121,84\% karena permasalahan literasi mereka terhadap aplikasi pembelajaran rendah, yang menghadapi permasalahan administrasi hanya 0,11\%. Permasalahan dan kendala yang dihadapi dosen melaksanakan pembelajaran dapat dilihat pada gambar dan tabel di bawah ini.

\section{MASALAH/HAMBATAN DOSEN DALAM KULIAH DARING}

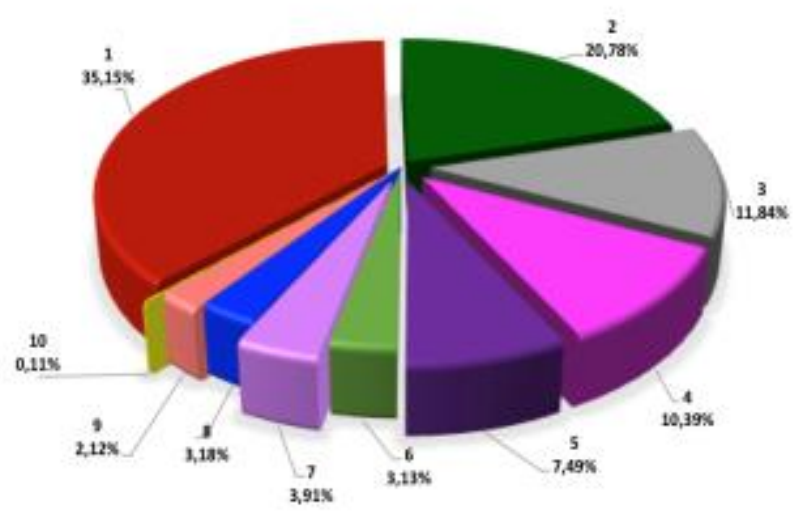

Sumber: Data Hasil Penelitian

Gambar 6. Permasalahan dan Kendala yang Dihadapi Dosen

Tabel 7. Permasalahan dan Kendala yang Dihadapi Dosen

\begin{tabular}{|c|c|c|}
\hline No & Permasalahan dan Kendala & $\begin{array}{c}\text { Persentase } \\
(\%)\end{array}$ \\
\hline 1 & Kesulitan signal atau jaringan & 35.15 \\
\hline 2 & Biaya dan keterbatasan kuota & 20.69 \\
\hline 3 & Literasi terhadap aplikasi rendah & 12.07 \\
\hline 4 & Kesulitan mengukur partisipasi dan sikap mahasiswa & 10.74 \\
\hline 5 & Aplikasi pembelajaran & 8.09 \\
\hline 6 & Perangkat pembelajaran & 3.85 \\
\hline 7 & Kesehatan, kelelahan, stress, jam kerja tidak menentu & 3.58 \\
\hline 8 & Kesulitan menerapkan model pembelajaran jarah jauh & 3.18 \\
\hline 9 & Potensi kecurangan atau plagiasi & 2.52 \\
\hline \multirow[t]{2}{*}{10} & Administrasi & 0.13 \\
\hline & Total & 100 \\
\hline
\end{tabular}

Sumber: Data Hasil Penelitian

Di samping terdapat permasalahan dan kendala di atas, dosen menilai perkuliahan secara daring mempunyai keuntungan atau kemudahan. Menurut dosen yang melaksanakan pembelajaran daring, pembelajaran dari memiliki keuntungan/kemudahan di antaranya pembelajaran dari bersifat fleksibel, akses mudah dan cepat, mahasiswa lebih aktif/belajar mandiri/disiplin, pengalaman menggunakan metode/aplikasi/media baru, sumber belajar lebih luas, mempermudah kerja dosen, dan sebagainya. Sebanyak 33,92\% dosen menganggap pembelajaran daring bersifat fleksibel, sebesar 21,76\% memperoleh kemudahan akses mudah dan cepat, sebesar $15,77 \%$ dosen menilai pembelajaran dari memfasilitasi mahasiswa belajar aktif/belajar mandiri/disiplin, dan hanya 2,79\% dosen memperoleh keuntungan aman dari virus.
Gambaran keuntungan dan kemudahan yang diperoleh dosen dalam pembelajaran daring dapat dilihat pada gambar dan tabel di bawah ini.

\section{KEUNTUNGAN/KEMUDAHAN DOSEN DALAM KULLAH DARING}

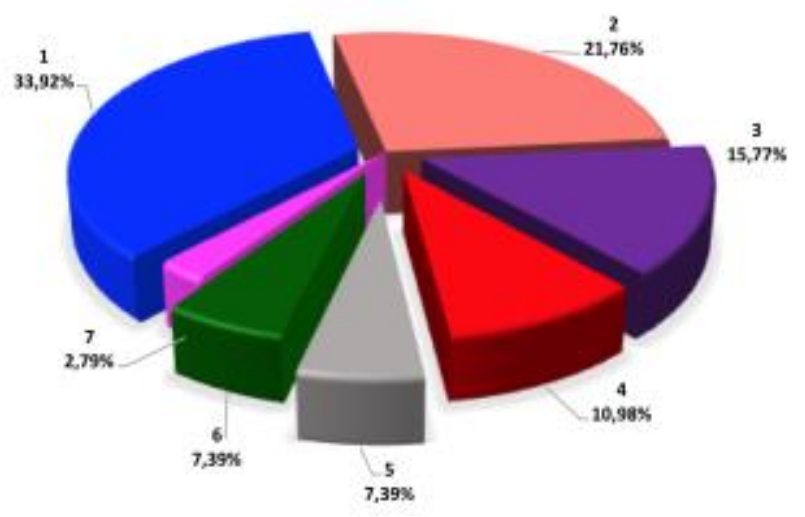

Sumber: Data Hasil Penelitian

Gambar 7. Keuntungan/Kemudahan Pembelajaran Daring

Tabel 8. Keuntungan/Kemudahan Pembelajaran Daring

\begin{tabular}{|c|l|c|}
\hline No & \multicolumn{1}{|c|}{ Keuntungan/Kemudahan } & Persentase (\%) \\
\hline 1 & Fleksibel & 33,92 \\
\hline 2 & Akses mudah dan cepat & 21,76 \\
\hline 3 & Mahasiswa lebih aktif/Belajar mandiri/Disiplin & 15,77 \\
\hline 4 & Belajar metode baru/ Aplikasi/Media & 10,98 \\
\hline 5 & Sumber belajar lebih luas & 7,39 \\
\hline 6 & Memperingan kerja dosen & 7,39 \\
\hline 7 & Aman dari virus & 2,79 \\
\hline & \multicolumn{2}{r|}{} \\
\hline
\end{tabular}

Sumber: Data Hasil Penelitian

Dalam melaksanakan pembelajaran daring pada masa Pandemi Covid 19 dosen menghadapi permasalahan dan kendala seperti telah diuraikan di atas. Untuk meningkatkan kualitas pelayanan kegiatan pembelajaran keada mahasiswa dosen memberikan saran perubahan dan perbaikan. Dosen mengajukan saran perubahan dan perbaikan di antaranya: sebesar 33,87\% dosen manyarankan perlu dilakukannya penyempurnaan Vinesa di SIAKADU, sebanyak 32,80\% menyarankan adanya bantuan fasilitas dari pemerintah, sebanyak 18,28\% menyarankan adanya pelatihan/persiapan/buku pedoman kuliah daring, dan hanya $0,54 \%$ dosen menyarankan adnya penyediaan perpustakaan digital. Saran perubahan dan perbaikan yang diajukan dosen dapat dilihat pada gambar dan tabel di bawah ini. 


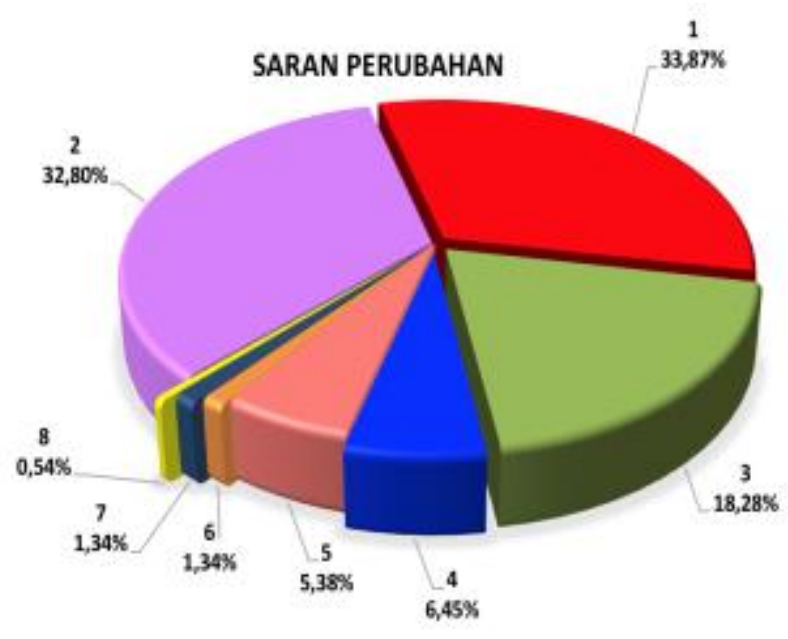

Sumber: Data Hasil Penelitian

Gambar 8. Saran Perubahan/Perbaikan Pembelajaran Daring

Tabel 9. Saran Perubahan/Perbaikan Pembelajaran Daring

\begin{tabular}{|c|l|c|}
\hline No & \multicolumn{1}{|c|}{ Saran Perubahan } & $\begin{array}{c}\text { Persentase } \\
(\%)\end{array}$ \\
\hline 1 & Penyempurnaan Vinesa & 33,87 \\
\hline 2 & Bantuan fasilitas & 32,80 \\
\hline 3 & $\begin{array}{l}\text { Pelatihan/ Persiapan/ buku pedoman kuliah } \\
\text { daring }\end{array}$ & 18,28 \\
\hline 4 & Tidak daring Realtime/ Recorder/ Blended & 6,45 \\
\hline 5 & kerjasama provider & 5,38 \\
\hline 6 & Perbaiki layanan administrasi & 1,34 \\
\hline 7 & Pengurangan tugas-tugas dosen agar tidak drop & 1,34 \\
\hline 8 & Penyediaan perpustakaan digital & 0,54 \\
\hline & \multicolumn{2}{|c|}{ Total } \\
\hline
\end{tabular}

Sumber: Data Hasil Penelitian

\section{PENUTUP}

\section{Simpulan}

\section{Kinerja Tendik Seluruh Unesa Berdasarkan Penilaian Atasan}

Berdasarkan penilaian atasan ini, untuk beberapa indikator kinerja tenaga kependidikan lebih baik daripada penilaian mahasiswa. Para Kasubbag memberikan apresiasi yang sangat baik dengan skor 3,31 terhadap kinerja tenaga kependidikan untuk inidkator atau aspek: (1) memberikan layanan sesuai dengan SOP; (2) bersikap ramah; (3) bersikap bersahabat; dan (4) mempunyai kemampuan kerjasama yang baik dalam menyelesaikan hasil kerja. Tenaga kependidikan dinilai sangat baik pada 4 aspek tersebut. Meskipun demikian atasan merasa belum puas terhadap kinerja tenaga kependidikan terkait dengan aspek pelaksanaan WfH, dilengkapi dengan fasilitas pribadi. Atasan menilai tenaga kependidikan yang melakukan pekerjaan dari rumah belum didukung dengan fasilitas pribadi yang memadai seperti prasarana meja dan kursi kerja, laptop, deskstop, printer, dan lain-lain.

\section{Kinerja Tendik Seluruh Unesa Berdasarkan Penilaian Mahasiswa}

Hasil riset menunjukkan bahwa mahasiswa memberikan penilaian sangat baik dengan skor rerata 3,21 terhadap kinerja tenaga kependidikan untuk semua indikator selama Pandemi Covid 19, baik selama bekerja di kantor maupun di rumah. Penilaian ini menunjukkan bahwa Tendik selama masa Pandemi Covid 19 tetap melaksanakan fungsi-fungsi pelayanan secara baik. Mahasiswa masih tetap merasa terlayani dengan baik meskipun secara daring, untuk urusan terkait dengan keuangan, registrasi, kelancaran perkuliahan, nilai, dan sebagainya.

Berdasarkan penilaian mahasiswa ini, untuk beberapa indikator kinerja tendik lebih rendah daripada penilaian atasan. Para mahasiswa memberikan apresiasi yang rata-rata sama untuk semua indikator. Dari hasil tersebut, sepertinya masih perlu ditingkatkan mengenai pelayanan tendik bagi mahasiswa, terutama di masa pandemik ini dimana sebagian besar pelayanan yang diberikan melalui on line. Hal tersebut dapat dilakukan dengan cara memberikan fasilitas jaringan internet yang memadai, baik di jurusan maupun memberikan bantuan paket data bagi tendik yang sedang WFH.

\section{Penilaian Mahasiswa terhadap Kinerja Perkuliahan Dosen Setiap Fakultas dan Pascasarjana}

Penilaian mahasiswa terhadap kinerja perkuliahan dosen setiap fakultas ini dikelompokkan dalam tiga kelompok yaitu kelompok persiapan, pelaksanaan, dan evaluasi. Hasil analisis data untuk kelompok persiapan menunjukkan bahwa Pascasarjana dengan skor 3,62 menempati skor tertinggi, disusul dengan Fakultas MIPA dengan skor 3,60, Fakultas Ilmu Sosial dan Hukum dengan skor 3,44, Fakultas Ilmu Pendidikan dengan skor 3,41, Fakultas Bahasa dan Seni dengan skor 3,39. Fakultas Ekonomi dengan skor 3,36, Fakultas Teknik dengan skor 3,34, dan Fakultas Ilmu Olahraga dengan skor 3,27.

Kelompok pelaksanaan menunjukkan bahwa Pascasarjana dengan skor 3,61 menempati skor tertinggi, disusul dengan Fakultas MIPA dengan skor 3,59, Fakultas Ilmu Sosial dan Hukum dengan skor 3,42, Fakultas Ilmu Pendidikan dengan skor 3,40, Fakultas Bahasa dan Seni dengan skor 3,38, Fakultas Ekonomi dengan skor 3,34, Fakultas Teknik dengan skor 3,32, dan Fakultas Ilmu Olahraga dengan skor 3,26.

Kelompok evaluasi menunjukkan bahwa Pascasarjana dengan skor 3,60 menempati skor tertinggi, disusul dengan FMIPA dengan skor 3,58, FISH dengan skor 3,40, FIP dengan skor 3,39, FBS dengan skor 3,38, FE dengan skor 3,34, FT dengan skor 3,33, dan FIO dengan skor 3,26 .

\section{Self Assesment Kinerja Dosen}

Data riset menunjukkan bahwa secara keseluruhan rata-rata mata kuliah yang menerapkan pembelajaran daring 77,29\% dan sebesar 18,51\% melaksanakan pembelajaran luring. Dengan kata lain, dari 1.821 matakuliah kegiatan perkuliahan daring sebanyak 21.569 tatp muka dan 6.107 tatap muka melaksanakan pembelajaran luring. Data ini menunjukkan belum semua 
matakuliah melaksanakan pembelajaran daring. Dapat diidentifikasi ada tiga kategori kegiatan pembelajaran selama Pandemi Covid 19 dan WfH, yaitu: pertama, kegiatan pembelajaran yang sepenuhnya daring (virtual learning); kedua, kegiatan pembelajaran campuran antara daring dan luring (blended learning); dan ketiga, pembelajaran yang sepenuhnya luring.

Fakultas Matematika dan Ilmu Pengetahuan Alam (FMIPA) merupakan fakultas yang kegiatan pembelajaran daringnya paling tinggi, yaitu sebesar $97,14 \%$ atau sebanyak 4.080 kali, sedangkan fakultas yang paling sedikit melaksanakan daring adalah Pascasarjana sebesar 63,69\% atau 414 tatap muka, hampir sama dengan FIP yang melaksanakan daring sebesar $69,62 \%$ atau 5.264 tatap muka.

Belum sepenuhnya matakuliah melaksanakan kegiatan pembelajaran daring terkait dengan permasalah dan hambatan yang dihadapi oleh dosen selama melaksanakan Tri Dharma dari rumah. Permasalahan dan kendala yang dihadapi oleh dosen selama WFH terkait dengan masalah-masalah non-akademik seperti signal atau jaringan internet, biaya dan keterbatasn kuota internet, literasi terhadap aplikasi pembelajaran berbasis teknologi informasi rendah, kesulitan mengukur partisipasi dan sikap mahasiswa, dan permasalahan dan kendala lain seperti tersaji pada gambar dan tabel di bawah ini. Sebesar $35,15 \%$ dosen mengaku menghadapi permasalahan dan kendala non akademik buruknya signal dan jarngan internet, sebesar 20,78\% menghadapi permasalahan biaya dan keterbatasan kuota internet, sebesar 121,84\% mengahadapi permasalahan literasi mereka terhadap aplikasi pembelajaran rendah, yang menghadapi permasalahan administrasi hanya $0,11 \%$.

Di samping terdapat permasalahan dan kendala di atas, dosen menilai perkuliahan secara daring mempunyai keuntungan atau kemudahan. Menurut dosen yang melaksanakan pembelajaran daring, pembelajaran dari memiliki keuntungan/kemudahan di antaranya pembelajaran dari bersifat fleksibel, akses mudah dan cepat, mahasiswa lebih aktif/belajar mandiri/disiplin, pengalaman menggunakan metode/aplikasi/media baru, sumber belajar lebih luas, mempermudah kerja dosen, dan sebagainya. Sebanyak 33,92\% dosen menganggap pembelajaran daring bersifat fleksibel, sebesar 21,76\% memperoleh kemudahan akses mudah dan cepat, sebesar $15,77 \%$ dosen menilai pembelajaran dari memfasilitasi mahasiswa belajar aktif/belajar mandiri/disiplin, dan hanya 2,79\% dosen memperoleh keuntungan aman dari virus.

Dalam melaksanakan pembelajaran daring pada masa Pandemi Covid 19 dosen menghadapi permasalahan dan kendala seperti telah diuraikan di atas. Untuk meningkatkan kualitas pelayanan kegiatan pembelajaran keadaan mahasiswa dosen memberikan saran perubahan dan perbaikan. Dosen mengajukan saran perubahan dan perbaikan di antaranya: sebesar 33,87\% dosen manyarankan perlu dilakukannya penyempurnaan Vinesa di SIAKADU, sebanyak 32,80\% menyarankan adanya bantuan fasilitas dari pemerintah, sebanyak 18,28\% menyarankan adanya pelatihan/persiapan/ buku pedoman kuliah daring, dan hanya $0,54 \%$ dosen menyarankan adanya penyediaan perpustakaan digital.

\section{Saran}

Berdasarkan hasil penelitian, pembahasan penelitian, dan pelaksanaan penelitian ini dapat diberikan beberasa saran seperti berikut ini.

1. Kinerja tendik oleh mahasiswa dan atasan dinilai sudah sangat baik tetapi ada indikator kinerja yang perlu ditingkatkan yaitu kinerja dalam memenuhi target kuantitas yang dibebankan dari pimpinan atau pengguna dan kerjasama antar tendik. Peningkatan ini dapat dilakukan dengan cara pemenuhan fasilitas kerja, pelatihan, dan memotivasi untuk membangun kebersamaan.

2. Bagi tenaga kependidikan, yang paling dirasakan menghambat kinerjanya adalah fasilitas pribadi yang sangat minim pada saat bekerja di rumah, maka tendik perlu mendapatkan perhatian dalam melengkapai sarana bekerja di rumah.

3. Kemampuan tendik dalam melakukan kerja di rumah yang harus dengan on-line juga perlu mendapatakan perhatian untuk ditingkatkan dengan cara diberikan pelatihan atau manual/panduan/pedoman aplikasiaplikasi utama yang digunakan.

4. Kompetensi dosen dinilai oleh mahasiswa sudah sangat baik tetapi ada indikator kinerja yang harus ditingkatkan yaitu respon terhadap hasil kerja mahasiswa. Mahasiswa merasakan dosen terlalu lama/lambat dalam merespon hasil kerja mahasiswa. Oleh karena itu indikator ini perlu ditingkatkan dengan cara memotivasi dosen untuk lebih mempercepat respon kepada mahasiswa.

5. Untuk peningkatan kualitas kuliah online disarankan adanya penyempurnakan vinesa, bantuan fasilitas, pelatihan/persiapan/buku pedoman kuliah, tidak daring realtime/recorder/blended, kerjasama provider, perbaikan layanan administrasi, dan pengurangan tugas-tugas dosen agar tidak drop.

\section{Ucapan Terima Kasih}

Penelitian ini didukung oleh dana Penelitian Skim Kolaborasi Dana Penerimaan Negara Bukan Pajak (PNBP) Batch-2 Tahun 2020, melalui Lembaga Penelitian dan Pengabdian Kepada Masyarakat (LPPM).

\section{DAFTAR PUSTAKA}

Daton, Darius Beda. 2020. Work From Home, Pelayanan Publik Masa Covid-19

Gold, L., \& Maitland, C. 1999. What's the difference? A review of contemporary research on the effectiveness of distance learning in higher education. Washington: Institute for Higher Education Policy.

Holmberg, B. 2005. The Evolution, Principles and Practices of Distance Education. Oldenburg Bibliotheks-und Informationssystem der. Carl von Ossietzky Universität Oldenburg.

Irene, Saleh, R. R., Foresto, B., Djuanda, R. E., Prayogo, A., Arianti, A., et al. 2020. Pesan Para Dokter terkait Covid-19. 
Rizal, Jawahir Gustav. 2020. "Akankah Work from Home Jadi Tren Setelah Pandemi Covid-19 Berakhir?"

Simonson, M. 2019. Distance Learning Journal (Book 2) (Vol. 16). Charlotte: Information Age Publishing.

Setiawan, A. R. 2020. Di Mana Letak Penting Lembaga Pendidikan? Dipetik April 6, 2020, dari Alobatnic: https://alobatnic.blogspot.com/2020/04/di-mana-letakpenting-lembaga-pendidikan.html

UNESCO. 2020. 290 million students out of school due to COVID-19: UNESCO releases first global numbers and mobilizes response. Dipetik Mei 9, 2020, dari UNESCO: https://en.unesco.org/news/290)-million-students-outschool-due-covid-19-unesco-releases-first-globalnumbers-and-mobilizes

https://www.jawapos.com/nasional/19/04/2020/solusipraktis-kelola-kehadiran-karyawan-di-masa-pandemicovid-19/

https://www.menpan.go.id/site/berita-terkini/pencegahanpenyebaran-virus-covid-19-dengan-kerja-di-rumahbagi-asn 